The Bangladesh Veterinarian (2008) 25(2) : 68 - 74

\title{
Productive and reproductive performance of dairy cattle in Char areas of Bangladesh
}

\author{
M. M. Alam*, M. J. U. Sarder, Z. Ferdousi ${ }^{3}$ and M. M. Rahman ${ }^{4}$ \\ Department of Animal Husbandry and Veterinary Science, Faculty of Agriculture, \\ Rajshahi University, Rajshahi-6205, Bangladesh
}

\begin{abstract}
Production traits of 60 indigenous (Desi), 20 Friesian $\times$ Desi and 20 Sahiwal $\times$ Desi cows were recorded in six char villages of Sariakandi upazila (Sub-district) of Bogra district. The mean $( \pm \mathrm{SD})$ daily milk yields were $1.7 \pm 0.6,6.3 \pm 1.2$ and $5.1 \pm 1.0$ litres, respectively. The lactation lengths, ages at puberty, gestation lengths, calving intervals, numbers of services per conception, intervals between calving and first oestrus were 217.9 $\pm 18.7,253.8 \pm 21.9,240.8 \pm 15.7$ days; $27.4 \pm 2.7,23.9 \pm 2.0,26.2 \pm 2.4$ months; $277.4 \pm$ $4.2,278.3 \pm 4.2,278.3 \pm 4.0$ days; $494.8 \pm 27.3,487.5 \pm 17.4,493.3 \pm 16.2$ days; $1.3 \pm 0.5$, $1.7 \pm 0.6,1.6 \pm 0.5 ; 145.6 \pm 27.4,166.8 \pm 33.0$ and $170.5 \pm 34.9$ days, respectively. Daily milk yield and lactation length were significantly $(\mathrm{p}<0.01)$ better for cross-bred cows than for Desi, and age at puberty was significantly $(\mathrm{p}<0.01)$ better for Friesian-cross cows than for Desi, while number of services per pregnancy and onset of post partum oestrus were significantly $(p<0.01)$ better for Desi than for cross-bred cows. There were no significant differences in gestation length and calving interval. It is suggested that the overall productive and reproductive performance of Friesian $\times$ Desi and Sahiwal $\times$ Desi cows were better than those of Desi cows. (Bangl. vet. 2008. Vol. 25, No. 2, 68-74)
\end{abstract}

\section{Introduction}

Chars are low-lying areas prone to flood and erosion in or adjacent to major rivers. About $80 \%$ of the poor and $36 \%$ of ultra-poor people in chars rear livestock as a major means of livelihood (Hodson, 2006; Howes, 2006). However, the productivity of cattle is low because of poor genetics, nutrition, herd health and management. Khan et al. (1999) reported that the cattle in Bangladesh are mostly of indigenous type (Bos indicus) with a few crossbreds, and some pure dairy zebus and European breeds such as Sahiwal, Sindhi and Holstein-Friesian. The very poor people living in the char areas of northern Bangladesh keep a significant number of unproductive cows, and are unable to ensure food security. It is imperative to improve productivity in order to increase food production and alleviate poverty.

There is paucity of information about productive and reproductive performance of dairy cattle in the chars in Bogra district. Comprehensive reports on productive potentials of Desi and crossbred cattle under various management conditions in

\footnotetext{
3Department of Genetics Engineering and Biotechnology, Faculty of Agriculture, Rajshahi University, Rajshahi, Bangladesh

4 Palli Karma-Sahayak Foundation (PKSF), Agargaon, Dhaka, Bangladesh

*Correspondence: E-mail:- mjhalam@yahoo.com
} 
Bangladesh are lacking (Alam and Ghosh, 1988; Nahar et al. 1989; Shamsuddin et al., 1988, 1995; Khan et al., 2001; Sarder, 2004; Rahman and Rahman, 2006). Prior to introduction of a crossbreeding programme for upgrading these cattle, it is essential to know the present production.

This study was undertaken to determine the productive and reproductive status of cattle in selected chars of Bogra district.

\section{Materials and Methods}

The study was conducted in six char villages of Sariakandi upazila of Bogra district from July to November 2007, in 60 indigenous, 20 Friesian $\times$ Desi and 20 Sahiwal $\times$ Desi. The indigenous cows are Zebu (Bos indicus) type, small in size. The information on production and reproduction was collected through interviewing farmers using pre-tested questionnaires, and data obtained from the farmers' cattle register. The following traits were used: daily milk yield, lactation length, age at puberty, gestation period, calving interval, number of services per pregnancy and onset of post-partum oestrus.

\section{Statistical analysis}

The data were analyzed using analysis of variance with Completely Randomized Design (Steel and Torrie, 1980). Modified Duncan Multiple Range Test (DMRT) was used for test of significance of means with unequal subclass number (Kramer 1956).

\section{Results and Discussion}

The mean values with standard deviation of the traits studied are presented in Table 1.

\section{Daily milk yield}

The mean daily milk production of Desi, Friesian $\times$ Desi cross and Sahiwal $\times$ Desi cross cows were $1.7 \pm 0.6,6.3 \pm 1.2$ and $5.1 \pm 1.0$ litres, respectively: the differences were significant $(\mathrm{p}<0.01)$. The results are consistent with those of Sultana et al. (2001) where daily milk production of Desi, Friesian $\times$ Desi and Sahiwal $\times$ Desi cows were 2.6, 7.2 and 4.9 litres, respectively. Our results partially agree with those of Ahmed and Islam (1987); Uddin et al. (2004); Rahman and Rahman (2006); Sarder (2001; 2006).

Globally, milk production increases $1.5 \%$ per year due to use of artificial insemination (AI), progeny testing, and intense selection of bulls. Milk yield is highly heritable, as cows produce more milk either by using ingested food or by mobilizing body fat (Schei et al., 2005). Management and nutrition are important for milk production and fertility (Windig et al., 2005; 2006). 
Table 1. Mean \pm SD of productive and reproductive performance of Desi, Friesian $\times$ Desi and Sahiwal $\times$ Desi cows in chars

\begin{tabular}{|c|c|c|c|c|}
\hline Parameters & $\begin{array}{l}\text { Desi cow } \\
(\mathrm{n}=60)\end{array}$ & $\begin{array}{c}\text { Friesian } \mathrm{x} \\
\text { Desi cross } \\
(\mathrm{n}=20)\end{array}$ & $\begin{array}{c}\text { Sahiwal } \mathrm{x} \\
\text { Desi cross } \\
(\mathrm{n}=20)\end{array}$ & $\begin{array}{l}\text { Level of } \\
\text { significance }\end{array}$ \\
\hline Daily & 1.7 & $6.3 \pm 1.2^{\mathrm{a}}$ & $5.1 \pm 1.0^{b}$ & $* *(\mathrm{p}$ \\
\hline Lactation length (days) & 217.9 & $253.8 \pm 21.9 a$ & $240.8 \pm 15.7 \mathrm{~b}$ & $* *(p<0.01)$ \\
\hline Age at puberty (months) & $27.4 \pm 2.7^{a}$ & $23.9 \pm 2^{b}$ & $26.2 \pm 2.4^{\mathrm{a}}$ & $* *(p<0.01)$ \\
\hline Gestation length (days) & $277.4 \pm 4.2$ & $278.3 \pm 4.2$ & $278.3 \pm 4$ & NS \\
\hline Calving inter & $494.8 \pm 27.3$ & $487.5 \pm 17.4$ & $493.3 \pm 16.2$ & NS \\
\hline $\begin{array}{l}\text { Number of services per } \\
\text { conception }\end{array}$ & 1.3 & $0.6^{\mathrm{a}}$ & $0.5^{\mathrm{a}}$ & $* *(p<0.01)$ \\
\hline $\begin{array}{l}\text { Onset of post partum oestrus } \\
\text { (days) }\end{array}$ & $145.6 \pm 27.4^{b}$ & $166.8 \pm 33.0^{a}$ & $170.5 \pm 34.9 \mathrm{a}$ & ${ }^{* *}(\mathrm{p}<0.01)$ \\
\hline
\end{tabular}

Mean values with different superscripts differ significantly, $(p<0.01)$. Parentheses indicate the total number of observation. SD = Standard deviation. NS = Non-significant

Lactation length

The mean lactation lengths of Desi, Friesian $\times$ Desi and Sahiwal $\times$ Desi cows were 217.9, 253.8 and 240.8 days, respectively. Lactation period of Desi cows was significantly $(\mathrm{p}<0.01)$ lower than those of Friesian $\times$ Desi and Sahiwal $\times$ Desi cows. The results are similar to those of Khan et al. (2001) who found that lactation length of Desi and Friesian $\times$ Desi cross were 221 and 281 days, respectively. Sultana et al. (2001) found that the lactation length of Desi, Friesian $\times$ Desi cross and Sahiwal $\times$ Desi cows were 221, 287.5 and 254 days, respectively. The present findings partially agree with those of Ahmed and Islam (1987); Mondal (1998), Uddin et al. (2004); Rahman and Rahman (2006); Sarder (2001; 2006); Sarder et al. (2007). But the results differ from those of Nahar et al. (1992) who found the average lactation length of Friesian $\times$ Desi cows was 330.5 days.

Age at puberty

The mean ages at puberty of Desi, Friesian $\times$ Desi cross and Sahiwal $\times$ Desi cross cows were 27.4, 23.9 and 26.2 months, respectively. The age at puberty of Desi cows was significantly $(\mathrm{p}<0.01)$ higher than that of Friesian $\times$ Desi. The results are similar to those of Sultana et al. (2001) who found that the ages at puberty of Desi, Friesian $\times$ Desi cross and Sahiwal $\times$ Desi cross cows were 25.2, 21.4 and 24.4 months, respectively. The present findings partially concur with those of Rahman and Rahman (2006); Sarder (2006); Sarder et al. (2007); Khan and Khatun (1998); Haque et al. (1999).

\section{Gestation length}

The mean gestation lengths of Desi, Friesian $\times$ Desi cross and Sahiwal $\times$ Desi cows were 277.4, 278.3 and 278.3 days, respectively. There was no significant 
difference between groups. The results are similar to those of Sarder et al. (2007) who found that gestation lengths of Desi, Friesian $x$ Desi and Sahiwal x Desi cows were 279.7, 278.2 and 278.8 days, respectively. The same was stated by Rahman and Rahman (2006); Nahar et al. (1992); Majid et al. (1995); Sarder (2006); Islam and Bhuiyan (1997); Uddin et al. (2004); Khan and Khatun (1998). They found that the gestation length of different genetic groups ranged from 270 to 284 days. The gestation lengths of the present study fall within that range.

\section{Calving interval}

The mean calving intervals of Desi, Friesian $\times$ Desi and Sahiwal $\times$ Desi cows were $494.8,487.5$ and 493.3 days, respectively. There was no significant difference between groups. The results are similar to those of Uddin et al. (2004) who found that calving intervals of Desi and Friesian x Desi cows were 484.1 and 489.2 days, respectively. Sultana et al. (2001) found that the calving interval of Sahiwal $\times$ Desi cows was 453.7 days. The present findings partially agree with those of Rahman and Rahman (2006); Sarder (2006); Sarder et al. (2007); Majid et al. (1995).

\section{Number of services per pregnancy}

The mean number of services per pregnancy of Desi, Friesian $\times$ Desi and Sahiwal $\times$ Desi cows were 1.3, 1.7 and 1.6, respectively. The number of services per pregnancy of Desi cows was significantly lower $(\mathrm{p}<0.01)$ than that of Friesian $\times$ Desi and Sahiwal $\times$ Desi. The result for Desi cows is similar to that of Rahman et al. (2006) who found that the number of services per pregnancy of Desi cows was 1.5. Sarder et al. (2007) stated that the number of services per pregnancy in Friesian $\times$ Desi and Sahiwal $\times$ Desi cows was 1.6. The present findings partially agree with those of Bhuiyan and Sultana (1994); Chwdhury et al. (1994); Rahman and Rahman (2006); Uddin et al. (2004).

\section{Onset of post partum oestrus}

The mean times to post-partum oestrus of Desi, Friesian $\times$ Desi and Sahiwal $\times$ Desi cows were 145.6, 166.8 and 170.5 days, respectively. The time for Desi cows was significantly $(\mathrm{p}<0.01)$ shorter than for Friesian $\times$ Desi and Sahiwal $\times$ Desi. The result for Desi cows is similar to that of Sarder et al. (2007) who found the time to post partum oestrus was 147 days. Uddin et al. (2004) stated that post-partum oestrus in Friesian $\times$ Desi and Sahiwal $\times$ Desi cows were 182.2 and 171.8 days, respectively. The present findings partially agree with those of Rahman and Rahman (2006); Majid et al. (1995).

It may be concluded that the overall productive and reproductive performance of Friesian $\times$ Desi and Sahiwal $\times$ Desi cows was better than that of Desi (indigenous) cows. Except for the number of services per pregnancy and time to post-partum oestrus, Friesian $\times$ Desi cows were best, followed by Sahiwal $\times$ Desi and Desi cows. On the other hand, the number of services per pregnancy (1.3) and time to post-partum 
oestrus (145 days) were better for Desi than for Friesian $\times$ Desi and Sahiwal $\times$ Desi cows. Therefore, an upgrading programme through crossbreeding with superior bulls' semen using $\mathrm{AI}$ is an option to enhance the genetic potential of these cows. However, unless we have more information on accurate phenotypes, there is an inherent risk that the genomic selection lacks proper counter-information on dairy cattle physiology, behaviour and pathological constraints, thus becoming less beneficial than expected

\section{References}

Ahmed Z, Islam TS 1987: Cattle breeding programme through artificial insemination in Bangladesh. A.I. Extension project Report Central Cattle Breeding Station, Savar, Dkaha pp 68.

Alam MGS, Ghosh A 1988: Reproductive performance of cows; its relation of parity and season. Bangladesh Veterinary Journal 22 51-61.

Bhuiyan AKFH, Sultana R 1994: Analysis of performance of exotic cattle breeds and their crosses in Bangladesh. Proceedings of the 5th World Congress on Genetic Applied to Livestock Production 20 355-358.

Choudhury MZ, Tahir MJ, Rafique M 1994: Production performance and milk producing efficiency in different groups of Holstein-Friesian $\times$ Sahiwal halfbreds. Asian-Australasian Journal of Animal Science 7 383-387.

DLS 2007: Department of Livestock Services, Government of People's Republic of Bangladesh, Khamar Bari Sharak, Farmgate, Dhaka.

DLS 2001: Department of Livestock Services, Government of People's Republic Bangladesh, Khamar Bari Sharak, Farmgate, Dhaka.

Haque KS, Amin MR, Hussen MS 1999: Dairy potential of Pabna cows and crossbreds with Sahiwal and Friesian and within and between breed sire effects. AsianAustralasian Journal of Animal Science 12 161-164.

Hodson R 2006: The Char Livelihood Programme: The Story and Strategy So Far. CLP Secretariat, RDA campus, Bogra.

Howes M 2006: An Introduction to the Char Livelihood Programme (mick.howes1@ ntlworld.com). CLP Secretariat, RDA campus, Bogra.

Islam SS, Bhuiyan AKFH 1997: Performance of crossbred Sahiwal at the Pabna milk shed area in Bangladesh. Asian-Australasian Journal of Animal Science 10 581-586.

Khan AA, Ali A, Hussain SS, Bhuiyan AKFH 1999: Reproductive performance of different genetic group of cows under farm condition. Bangladesh Journal of Animal Science 28 59-64.

Khan MS, Islam MN, Hashem MA, Sultana Z 2001: Milk productive performance of indigenous and crossbreds cows of private dairy farm. Bangladesh Journal of Animal Science 30 15-19.

Khan MKI, Khatun MJ 1998: Performances of $F_{1}$ crossbred cows at Baghabarighat milk shed area. Bangladesh Journal of Animal Science 27 183-186 
Kramer CY 1956: Examination of multiple range tests to group means with unequal numbers of replication. Biometrics 12 307-310.

Majid MM, Nahar TN, Talukder AI, Rahman MA 1995: Reproductive performance of pure breed, $F_{1}, F_{2}$ and $F_{3}$ cows related at Savar Dairy Farm. Bangladesh Journal of Livestock Research 2 53-62.

Mondal SC 1998: A comparative study on the production performance of different dairy breeds of BAU Dairy Farm. MS Thesis. Department of Dairy Science, Bangladesh Agricultural University, Mymensingh.

Nahar N, Mostafa KG, Amin MR 1989: A comparative study on the performance of F. crossbred cows. Bangladesh Journal of Animal Science 18 55-62.

Nahar TN, Islam M, Hasnath MA 1992: A comparative study on the performance of F. crossbred cows, under rural conditions in and around the BAU campus, AsianAustralasian Journal of Animal Science 5 435-438.

Rahman M, Rahman MM 2006: Productive and reproductive performance of native cows under farm condition. Asian Journal of Animal and Veterinary Advances 1 13-17.

Sarder MJU 2004: Genetic variation in semen characteristics relation to fertility of some pure and cross-bred Al bulls. PhD Thesis, Department of Genetics and Breeding, Faculty of Agriculture, Rajshahi University, Bangladesh.

Sarder MJU 2001: Reproductive and productive performance of indigenous cows. The Bangladesh Veterinarian 18 123-129.

Sarder MJU 2006: Study on the influence of sire on reproductive and productive capability of dairy cows used for artificial insemination programme at greater Rajshahi district. Rajshahi University Studies, Part-B, Journal of Science 34 237-253.

Sarder MJU, Rahman MM, Ahmed S, Sultana MR, Alam M, Rashid MM 2007: Consequence of dam genotypes on productive and Reproductive performance of dairy cows under the rural condition in Bangladesh. Pakistan Journal of Biological Science 10 3341-3349.

Schei I, Volden H, Baevre L 2005: Effects of energy balance and metabolizable protein level on tissue mobilization and milk performance of dairy cows in early lactation. Livestock Production Science 95 35-47.

Shamsuddin M, Alam MGS, Ahmed JU 1988: Reproductive disorder of cross bred cows. Bangladesh Veterinary Journal 22 151-58.

Shamsuddin M, Rahman MA, Sarder MJU 1995: Management related variations in the health and fertility status of cows in mini-dairy farms. Bangladesh Journal of Animal Science 24 7-17.

Steel RGD, Torrie JH 1980: Principles and Procedures of Statistics. McGraw-Hill book Co. New York.

Sultana N, Rahid MM, Hossain SMJ 2001: A comparative study on productive and reproductive performance of different cross-bred and indigenous dairy cows under small scale dairy farm condition. Pakistan Journal of Biological Science 4 1036-1037. 
Uddin MM, Islam MN, Hossain MN, Ahmed S 2004: Reproductive performance of different genetic groups of dairy cows under ideal management condition. Journal of Bangladesh Agricultural University 2 99-102.

Windig JJ, Calus MPL, Veerkamp RF 2005: Influence of herd environment on health and fertility and their relationship with milk production. Journal of Dairy Science 88 335-347.

Windig JJ, Calus MPL, Beerda B, Veerkamp RF 2006: Genetic correlations between milk production and health and fertility depending on herd environment. Journal of Dairy Science 89 1765-1775. 